\title{
ALAO 1987
}

By Darwyn J. Batway

Director of the Library

Ashland College

\section{and Janice Marotta}

Head, Serials and Government

Documents/Microforms

Ashland College

\section{The Conference of the Academic Library Association of Ohio, Columbus, October 15-16, 1987.}

$\mathbf{T}$ he Academic Library Association of Ohio (ALAO) held its thirteenth annual meeting at Columbus on October 15-16. ALAO has a welldefined purpose and organizational structure and exercises a needed leadership role for academic librarians in Ohio. ALAO emerged with its own identity in 1974 when it organized a preconference to the Ohio Library Association's annual meeting. In the 1981 ALAO midwinter meeting, the Association of College and Research Libraries' board approved ALAO's request to be Ohio's ACRL chapter. ' In recent years, ALAO has exercised a statewide influence on library instruction for high school and college students. ${ }^{2}$

Librarians from thirty-six colleges and universities, including one retired librarian, and representatives from at least four major library associations gathered for this year's conference, "1987: The Year of the Reader." One of the conference's speakers, Frederic G. Cassidy, also represented the Dictionary of American Regional English project.

October 15 served as an introduction to the main conference with an all day workshop conducted by Zena Zumeta, an attorney and owner/director of the Ann Arbor Mediation Center. The workshop's theme was "Managing Workplace Conflict." Its objective was to provide those who work in libraries with a set of skills and an ability to handie

${ }^{1}$ See Linda K. Hinrichs, "ALAO and OCA," ALAO Newsletter 9 (June 1982):5-6.

${ }^{2}$ Ohio Library Association Task Force on Library Instruction, "Primed for Success," OLA Bulletin 56 (October 1986): 26-33. conflicts among personnel or departments. Registration was held to fifty.

The main program began early on October 16 . While the remainder of the conference's 150 participants registered, a concurrent information meeting was conducted for those librarians who act as liaison representatives between their own member libraries and ALAO. This supported an agreement by ALAO officers, board members and committee chairs in a leadership conference on July 6 and 7 in Dayton. Members decided that emphasis for this year would be on increasing membership and strengthening the role of library liaisons to ALAO.

Linda Landis, ALAO President (Columbus State Community College) offered a formal welcome to participants. This year's program was intended to be less technically oriented than previous conferences. This was reflected in the tone set by the introductory speaker, David Kaser (distinguished professor at the School of Library and Information Science, Indiana University).

"A Reading Academic Librarian in the 21st Century" was the title of Kaser's address. This was somewhat misleading because Kaser did not examine reading habits but rather the enduring problems of librarianship. He affirmed that people in society are perceived to succeed without using libraries, and these are quite often the so-called pillars of society. He has found the cost and rationale for libraries to be major concerns for a substantial part of his career. He recalled presenting a library budget to a board of trustees meeting at Cornell University twenty years ago. A wealthy member of the board challenged him to explain what the li- 
brary could do for the University that was worth the cost. After twenty years of research, administration and teaching, he contended that there has

\section{A preview of programs at Annual Conference in New Orleans}

The following ACRL programs have been approved for ALA Annual Conference in July. Program titles are tentative at this point, but should be generally accurate. Date and time will be given in the May 1988 C\&RL News.

ACRL President's Program: "Fostering Creativity and Innovation."

Copyright Committee: "Copyright Is Still with Us: A Reawakening of the Issues Posed by New Technologies."

Legislation Committee: "Information Access: Issues and Action."

Anthropology and Sociology Section/Western European Specialists Section: "Strangers in New Worlds: Migration Studies in Europe and America."

Art Section: "Jazz in the Arts: Photography, Film, Dance and Music Collections."

Asian and African Section: "Preservation of Asian and African Materials."

Bibliographic Instruction Section: "Teaching CD-ROM."

College Libraries Section: "Collection Development Issues in the Mid-Sized and Smaller Academic Library."

Community and Junior College Libraries Section: "Optical Disk Technology and All That Jazz."

Education and Behavioral Science Section: "The Role of Libraries, Collections, and Education/Behavioral Sciences Librarians in Accreditation Review."

Law and Political Science Section: "Information Policies of International Organizations: Roadblocks to Access."

Rare Books and Manuscripts Section: "Government Documents As Rare Books," and "Insider Theft and Misappropriation by Trusted Employees in Libraries."

Science and Technology Section: "Integrated Information Systems and Libraries."

Slavic and East European Section: "New Technology for Slavic and East European Librarianship."

University Libraries Section: "Retention of Academic/Research Librarians: How and Why to keep the Staff You Have."

Women's Studies Section: "Women in Third World Countries: Research Trends and Collection Development Challenges."

Engiish and American Literature Discussion Group: "The American and English Literature of the 21st Century." not been a truly satisfactory answer. Why libraries should exist or why they are worth the cost cannot be taught. There is likewise no catechism of questions and answers for graduates of library schools that will enable them to answer the innumerably uninformed questions that society poses about libraries. Quite simply, libraries exist because people write books, not because people necessarily read them. The role of the 21 st-century librarian will remain essentially what it is today. He or she will acquire, organize, preserve and deliver the written record. The format of these functions may change, but the functions will endure. In response to the issue of cost, Kaser suggested that members of the profession might ask society what it really wants from librarians. Unfortunately, society often wants things cheaply.

Following Kaser's address, participants were able to select from several one-hour sessions. One of these sessions was led by William J. Studer (director of the Ohio State University Libraries) and Donald L. Tolliver (director of the Kent State University Libraries). The session was entitled, "Access to Information: Ohio Board of Regents' Library Facilities Inquiry." Both speakers were part of a five-member board commissioned by the Ohio Board of Regents to look into the storage and space problem in state-supported academic libraries in Ohio and to offer suggestions. The committee looked at thirteen universities, two free-standing medical college libraries and fifty two-year campuses. Various problems that the committee investigated as well as solutions to those problems were discussed. The most glaring problems were space and money.

For purposes of the committee's study, space in libraries was divided into three types: low, medium and high density. Low density represents the traditional call number shelf order. Medium density is the compact shelving type of storage. High density storage appeared to the committee to be the way of the future for libraries to solve space problems. This type of storage does not use call number order for shelving. In this system, each book has a series of barcodes that identifies the book, its range, shelf and storage box location. This makes it possible to depart from traditional library concepts of arrangement and to shelve books by size. High density storage requires restricted access and is best employed for rarely used items.

Traditional shelving arrangement is recommended for those items that are in frequent demand. One recommendation made by the committee with an impact on libraries in Ohio is that a high density storage facility be built at the Ohio State University. Other recommendations to the Regents include a proposal that the State of Ohio impose a restriction on building traditional library spaces unless there is a definite need, collaborative efforts for storage on a regional basis among libraries, state assistance in the conversion of holdings to machine-readable formats, the develop- 
ment of a statewide distribution system, monitoring of technology, and the establishment of an oversight committee. These and other recommendations with discussion can be found in the committee's report available through the Ohio Board of Regents. ${ }^{3}$

Following lunch and a business meeting, participants were treated to a presentation on the Dictionary of American Regional English project. Allyn Ehrhardt (Franklin University) formally introduced Frederic G. Cassidy (University of Wiscon$\sin$ ), chief editor of the project's first volume. ${ }^{4}$ Cassidy has helped guide the project as director-editor since 1965. His discussion highlighted the project's history in a most entertaining and occasionally anecdotal manner, although it did not substantially enhance the information already available to librarians in the first volume of the Dictionary. ${ }^{5}$

The second session of the Conference featured a particularly informative presentation on access to U.S. government information. Carol Singer (Kenyon College), Saragail Lynch (Ohio State Univer-

\footnotetext{
${ }^{3}$ Ohio Board of Regents Library Study Committee, Academic Libraries in Ohio: Progress Through Collaboration, Storage and Technology (Columbus: Ohio Board of Regents, September 1987).

${ }^{4}$ Frederic G. Cassidy, ed., Dictionary of American Regional English (Cambridge, Mass.: Belknap Press of Harvard University, 1985), vol.1.

${ }^{5}$ Frederic G. Cassidy, Dictionary, vol.1, "Introduction," pp. xi-xii, and "Language Changes Especially Common in American Folk Speech," pp. xxxvi-xl.
}

sity) and Mary Prophet (Denison University) led a session entitled, "The Tightening Noose: Decreasing Access to U.S. Government Information." Their discussion centered on the concern many librarians are expressing with the decreased access to information available from the government within the last seven years. Libraries have seen the conversion to microfiche of many items formerly published in paper format along with the cessation of many other topics. ${ }^{6}$ However, a close look at the list points to the fact that certain types of much needed information are quietly being retired without discussion or input from the public.

The major concern at the moment is the privatization of the National Technical Information Service (NTIS) ${ }^{7}$ This has not happened yet, but it is being seriously investigated. A substantial amount of technical information distributed by this department would cease to be available at a price that most libraries could afford if privatization should occur. All participants were urged to communicate their concerns to their Congressmen and other members of the government in an effort to effect some positive results.

The 1988 ALAO is scheduled for the first week in November in Columbus.

\footnotetext{
${ }^{6}$ Karen Sinkule, "Problems with Promoting Use of Microform Documents," $R Q 26$ (Fall 1986):21-29.

${ }^{7}$ Marilyn Moody, "The Privatization of NTIS: What Are the Implications?" $R Q 26$ (Winter 1986):157-62.
}

\title{
RESARAREH:ETBICATIONS
}

\section{Guaranteed availability, when you want them.}

\author{
Journals of Science, Technology, \\ and Medicine in microform.
}

Every title filmed and delivered-from the first issue forward. Current subscriptions are delivered within three months of the end of the volume year, and availability of all backfiles is guaranteed. For complete title listings and prices, call 1-800-REACH-RP (1-800-732-2477) now. From Connecticut, Alaska and Canada, call collect (203) 397-2600.

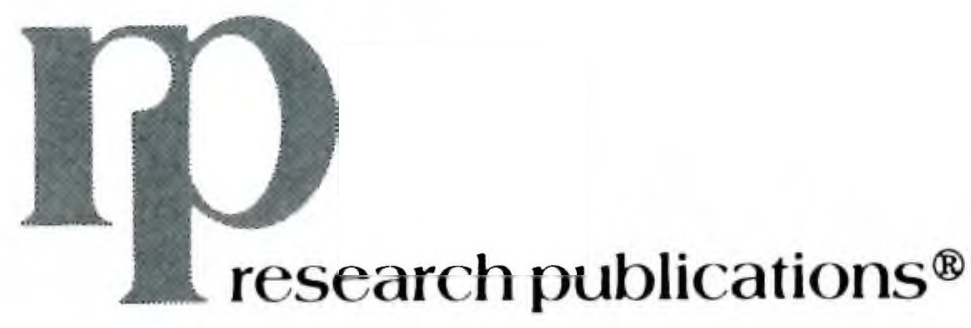


Some things are more

timely than others...

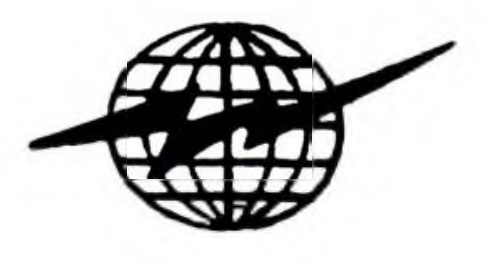

\section{DISCOVER THE WORLD \\ OF LIBRARY AND \\ INFORMATION SCIENCE}

\section{with Library Times International}

a timely bimonthly journal offering a unique single source for:

- World News

- Information Science Update

- Provocative Interviews

- Probing Editorials

- Special Reports on Conferences

- New Publications

- Calendar of National and International Conferences

- Book Reviews

- Articles

- And Much More ...

There is no better medium than Library Times International to reach the library and information science world. It is the only journal which brings librarians, library educators, information scientists and others together from all continents.

Subscription rates: $\mathbf{\$ 2 0 . 0 0}$ (U.S.) for institutions; $\mathbf{\$ 1 4 . 0 0}$ for individuals, foreign subscribers add $\$ \mathbf{\$ 7 . 0 0}$ for airmail and $\$ \mathbf{3 . 0 0}$ for surface mail.

Free sample copies are available.

Send orders to:

Library Times International, Subscription Department, P.O. Box 375, Oshkosh, Wisconsin 54902, U.S.A. 